\title{
Chris Kemp
}

\section{The development of the Moravian folk ethic, through the transplantation of its cultural roots into the arena of contemporary western recording technology}

\section{A historical perspective of Moravian folk music}

Moravian folk music came to prominence during the baroque period of the 14th and 15th centuries. There was no science to Czech folk music, it was a traditional way of playing and living. In 1895 there was a large exhibition of folk culture in Prague, which pricked the conscience of the people and the science of folk music, was developed. The folk culture had always been closed to other elements from other cultures and as will become apparent later resisted all overlords who tried to change this fundamental core of Czech $^{1}$ culture. The closed nature of Czech folk music sprang from its ability to exist around the seasonal working practices of the people. The people lived their folk culture, they did not deviate from its heart, nor did they change their folk fashion. The developmental period for and the recognition of the Moravian folk culture was during the baroque era. The inhabitants of the castle within Kyjov, would invite folk musicians to play at parties, balls and concerts. After the exhibition in Prague in 1896 the development of Moravian folk culture became recognised by the country as a whole. The Czech culture tended to preserve its own interests. Hymns were sung in church and then modified by the villagers into folk songs. This record was then published and known as Gubernialni Sbirka, a collection of regional folk songs, and was published in Straznice. More has been documented on the development of Moravian music. Entertainment and music gives people joy and excitement and they spend a lot of time developing technique and socialising with other people of a like mind. The difference between contemporary music and traditional folk music is a difference in attitude and context. Folk music is not just an interest: you are also part of it, it is your culture. Since the velvet revolution there have not been many structures or contextual changes within Moravian folk music. However, one change, which is felt to be disturbing by a number of musicians and observers, is the development of new technologies and western influences which threaten to undermine the traditional cultural values of Moravian music. The producer who had knowledge from a number of recordings made in the past, which then used this knowledge to record the Moravian

\footnotetext{
${ }^{1}$ It must be remembered that an independent Czechoslovak republic was not founded until the collapse of the Hapsburg Empire in 1918. The Slovak lands were part of Hungary in the 9th C. This lasted until 1918. A cohesive Czech state emerged in Bohemia and Moravia between the 10th and 12th C. after the Velvet Revolution in November 1989, The Czech and Slovak Republics were formed in their own right. Therefore this must be borne in mind when there is any mention of Czech culture or Czech lands.
} 
music using past experiences to develop the recording process. With the development of technology more people can become musicians. Under the communist regime, whatever was created within the folk of the Czech Republic was subsumed by communist cultural influences creating a false perception of Czech culture by the oppressors. They took ownership of the subsumed culture and portrayed this culture to the outside world as their own. The economic situation of music within Czech folk culture is very different from that within Western Europe. Principally, the basic ideals behind Western European music usually revolve around economic factors; however, the ideals behind music in the Czech Republic are steeped in cultural values. The communist regime, however, did invite groups to play at special festivals and paid their expenses. The communist regime attempted to control the cultural practices of the Czech people. There were two ways that the indigenous culture could be preserved under a communist regime; firstly, through normal channels where the communists believed that the Czech culture was now their own. The costumes are still worn as part of the music culture, and the folk music and dance are still preserved in both their original form and a developed form. The developed form stems from lessons learned and a culture saved within the Czech psyche.

\section{Promotion of Moravian music}

Moravian folk ensembles and other Czech folk ensembles are promoted quite differently from Western European ensembles. There is a large meeting of folk bands from all over the Czech republic in Prague once a year and the meeting will have themes such as soldiers' songs, love songs or joy songs.

There are a number of main festivals in the Czech Republic. The two other huge festivals celebrated in the Czech republic are of course Easter and Christmas.

As far as records are concerned, the Prague group does not want to record a record; their taped performance is for their own use. The group has to want to be recorded and someone from the group has to arrange it.

\section{A historical perspective on Moravian folk culture and customs}

Moravian folk culture is part of their lives. Around Kyjov, each village will have its own distinctive folk culture. They are all linguistically very close and have this underlying factor in common. The history of Kyjov is as follows:

1126 The first written record of Kyjov's existence

1284 Wenceslas gave permission for the town to be fortified

1515 A red seal was used to proclaim it as a town

\section{Details pertaining to Moravian folk music}

Moravian folk music is extremely difficult to write down or record. Moravian folk music is extremely distinctive. In one town two ensembles may play the same piece of music but in different tempos. Singers tend to lead the ensemble, and the musicians play in accordance with the singers. The ensembles are constantly searching through their records for old songs that have not been performed before. They become an 
ethnographic group trying to keep the culture alive. The song is then spread and eventually it becomes a local folk song that the entire village or even the whole region knows.

These folk songs are in verse form with a chorus. Through the 70's into the mid 80 's the ensembles had to limit the religious elements in their music and song owing to the Communist regime which oversaw the production of culture in Moravia and the Czech Republic. A great many people saw folk culture as a refuge and they lived within their culture a lot more intensively than they normally would have done. The culture contains such a broad spectrum of feeling songs are a great way of expressing contrasts. The usual contrast that was expressed during the period of communist occupation was the difference in the way culture was perceived by the communists and the Czech people. The songs and dances often originate from work and free time, they form a structured communication system.

There are adult dance ensembles, adult male choirs, adult female choirs, teenage preparation groups, groups for teaching children before they go into teenage prep groups, etc. For the 1995 folk festival the planning started in September/October 1993. There were records, CD's ${ }^{2}$ cassettes and posters to be prepared. Folk culture is going through a big revival; the level of musicianship, musical education and interest is very high. Before the recording session in England, two of the members of Hudci were recording with another band at Brno radio station studio using the professional recording facilities and engineers. The band pays for the recording and sells the record to their friends and audience. A radio station may record a programme and publish excerpts. Sometimes the radio engineers may go to a barn to record a band. The folk idealism of Moravian culture is an attitude of mind. One of the most fascinating aspects of this culture is the way in which the music, the festivals, the ceramics and even the food portray an existence lost in time to the western world through pure greed and the denial of their own underlying folk culture.

\section{The administration of Moravian folk music today}

There is nothing available from the State authorities for music in Moravia.

The administration of local music is very different from the way in which western society funds music. The major venue for folk music in Kyjov is the wine cellar. The theatre has a number of folk events but the wine cellar has the largest number of folk events during the year.

The wine cellar gets $40,000 \mathrm{cks}^{3}$ because it features cimbalum ${ }^{4}$ music. Next to the town hall in Kyjov is the house of culture. A grant from the local authority covers all the cultural activities including classical music and discos. There is no national funding in Kyjov. There are many businesses within the Czech Republic who could give enormous funds to music and the arts but choose not to ${ }^{5}$. Theoretically if someone locally sponsors culture they get a tax benefit. It is, however, in the local interest that

\footnotetext{
${ }^{2}$ Where the initials $\mathrm{CD}$ arise within this paper they are always describing compact discs.

${ }^{3}$ This equivalent to $£ 1000$ at the time of printing.

${ }^{4}$ The cimbalum is similar to the inside of a piano where the strings are hit with two wooden sticks.

${ }^{5}$ There is a lack of knowledge through poor education regarding arts funding. This therefore inhibits companies providing funds for the arts even though there are a great many benefits in this.
} 
local art is supported by the local authority, as it preserves and perpetuates local indigenous culture through those agencies within the community supporting local artists, within a brief prepared by those who understand and develop the local culture. In Bohemia, for example, where national resources were used to preserve local culture, the culture it was trying to preserve quickly died out, being replaced by a tourist culture far removed from the original indigenous culture.

\section{The quadrennial international folk festival}

The quadrennial International Folk Festival is the oldest folk festival in the Czech Republic and the most prestigious event held in the Kyjov area. The total amount of funding gained for the festival is $1.200 .000 \mathrm{cks}$ and the festival runs at a loss of 200.000 cks. Culture is the last thing that receives funding. $6 \%$ of the budget is put aside for culture. One film crew from Czech TV was always present from the news and culture programme.

\section{The preservation of culture and the influx of Western trends}

Local young people are well aware of new trends, especially in Western European music; new CD's are available in larger towns in the Czech Republic. The influx of capitalist culture into the Czech Republic has not demeaned the worth of culture within Kyjov. If local culture can survive occupation by Germany and communism it can survive anything.

The preservation of culture is through the family and education systems. There is a local school of art with folk culture specialising in visual and performing arts within Kyjov. The Kyjov folk ensemble has a children's group, a junior group and an adult group, and children graduate through each one.

Western European culture is different from Eastern European culture. In the Renaissance period working women wore $17 \mathrm{C}$ folk costume ${ }^{6}$, song arrangements and dances are encapsulated in the same style. Everything in the culture of Kyjov is authentic.

The dances take place alongside the music for visual effect and storytelling content. A number of people complained that the folk festival was too organised and professional. Most bands play free at the Kyjov festival but bands at the wine cellar are paid to perform. Changes through the generations have not destroyed the culture, the Moravian people are much more in touch with nature. Folk music in the region is not dead, it develops as culture changes.

\section{Moravian musicians visit to Britain}

After a number of study visits to the Czech republic, the author befriended a group of Folk musicians collectively known as Hudci. The Czech psyche has developed a longing for adventure and travel.

\footnotetext{
${ }^{6}$ What is termed here as $17 \mathrm{C}$ folk costume would have been considered as normal work wear in the Renaissance.
} 


\section{The introduction to the studio and studio manager}

Tony Platt the rock producer was invited to produce the Moravian album. On entry to the studio environment the technology and the vastness of the recording space overwhelmed the band. In the past the musicians had been used to recording in radio studios with a few hours to record a full $C D$. They were now faced with up to date technology, a week to record and a vast space to record in.

The band was able to contribute to each part of the recording, mixing and mastering process. Each song was then fully rehearsed without any recording with the producer sitting in with the musicians. By understanding the band's concerns and producing the correct ambience within which the band could work, the producer was now totally trusted. The musicians felt that they could now cope with both the recording technology and the processes that were entailed in producing the $\mathrm{CD}$. Each peice was recorded four times and then played back to the musicians. The development of the younger musicians liking for western culture was extremely marked and each of the four younger males and the two young females spent hours clubbing, drinking and sharing western cultural experiences with the students. In return the students learned a new language, some new songs and spent hours singing and playing blues and jazz with all the musicians. The development not only of their music but the way in which their culture totally accepted the developments as read showed their total adaptability to new media and form. The first is concerned with global factors that affected the Moravians during the recording process, and the second details the factors which affect individuals within the group and the Moravians as a group isolated through their cultural displacement. The following seem to be the global factors which affected the behaviour and experience of the Moravian band Hudci whilst recording in the studio.

The first factor concerns the technology itself. The updating of technology seems to hold no fears for the developing musicians within the Czech Republic. The availability of such technology to groups like Hudci in the Czech Republic is very limited. The cost therefore to the musicians is three fold, firstly the studio time costs, which will be extended if the band need to develop their competence with the technology. Although the musicians in Hudci have funded their trip to England themselves and the studio paid for the entire recording process, this is not the norm. The cost of producing a CD in a Czech Republic radio station would be around 40-60.000cks for studio time and then a further cost for the production of the $\mathrm{CD}^{7}$. The third factor is a socio/cultural one. The more you invest the more people want to record there. The musicians on arriving at the studio were unaware of the exact specification of the recording technology. Though the development of the recording process was the primary aim of the Czech musicians this was modified through time. Temporal cycles affect the very grounding of Czech culture. The music grew from the earth and therefore the earth embodies both the struggle and the beauty of the Czech culture. In a Western European culture such as Great Britain, rather than revolving around the seasons the culture revolves around the economic viability of festivals. Western style culture has not yet reached many places deep in the agricultural areas of the Czech Republic and the actual cultural festivals are linked more to religion than the economy

\footnotetext{
${ }^{7}$ The cost of the production of the CD in Great Britain using the type of technology provided by INFX studio for the project would have been almost ten times the amount that it would have cost to produce the $\mathrm{CD}$ in Brno.
} 
or the economic growth. The attitude of the musicians to their culture did not change throughout the experience. The musicians spent each evening searching for western cultural experiences to compare and contrast with their own culture. There were ten students involved in the recording process. The great majority were sceptical before the arrival of the band, showing a distaste for folk music. Looking back at Czech History this attitude to their culture is one of their greatest assets and this attitude pervades Czech society and shone through in the recording process.

One other major micro and macro factor concerns access, education and information, which are major factors in the use of high level technology in the recording industry. This dual system seems to work well for the majority of bands but groups like Hudci who are at the transition between popular Czech cultural music and a more westernised approach to arranging folk music need to have access to such studios. The cultural roots of this ethic seem to have been transplanted into contemporary western recording technology. The development of the folk ethic could have perhaps been less tenuous had the recording process undertaken by the musicians lasted longer. It can be seen that temporal, financial, geographical and social factors affect the way that music is produced in the Czech Republic. It became apparent during the recording process that the transplantation of the group Hudci into a western recording technology base enhanced and developed the way in which they perceived their own culture, as well as that of a Western European country. 